\title{
IODP workshop: developing scientific drilling proposals for the Argentina Passive Volcanic Continental Margin (APVCM) - basin evolution, deep biosphere, hydrates, sediment dynamics and ocean evolution
}

\author{
Roger D. Flood ${ }^{1}$, Roberto A. Violante ${ }^{2}$, Thomas Gorgas ${ }^{3}$, Ernesto Schwarz ${ }^{4}$, Jens Grützner ${ }^{5}$, \\ Gabriele Uenzelmann-Neben ${ }^{5}$, F. Javier Hernández-Molina ${ }^{6}$, Jennifer Biddle ${ }^{7}$, Guillaume St-Onge ${ }^{8}$, and \\ APVCM workshop participants* \\ ${ }^{1}$ School of Marine and Atmospheric Sciences, Stony Brook University, Stony Brook, New York \\ 11794-5000, USA \\ ${ }^{2}$ Argentina Hydrographic Survey, Buenos Aires, C1270ABV, Argentina \\ ${ }^{3}$ GFZ German Research Centre for Geosciences, 14473, Potsdam, Germany \\ ${ }^{4}$ Geological Research Center, University of La Plata - CONICET, B1904DPK, La Plata, Argentina \\ ${ }^{5}$ Alfred-Wegener-Institut Helmholtz-Zentrum für Polar- und Meeresforschung, 27568 Bremerhaven, Germany \\ ${ }^{6}$ Department of Earth Sciences, Royal Holloway, University of London, Egham, Surrey TW20 0EX, UK \\ ${ }^{7}$ School of Marine Science and Policy, University of Delaware, Lewes, Delaware 19958, USA \\ ${ }^{8}$ Institut des Sciences de la Mer de Rimouski, Université du Québec à Rimouski, Rimouski, Québec, \\ G5L 3A1, Canada \\ *A full list of authors and their affiliations appears at the end of the paper. \\ Correspondence to: Roger D. Flood (roger.flood@ stonybrook.edu)
}

Received: 21 November 2016 - Revised: 9 February 2017 - Accepted: 13 February 2017 - Published: 31 May 2017

\begin{abstract}
The Argentine margin contains important sedimentological, paleontological and chemical records of regional and local tectonic evolution, sea level, climate evolution and ocean circulation since the opening of the South Atlantic in the Late Jurassic-Early Cretaceous as well as the present-day results of post-depositional chemical and biological alteration. Despite its important location, which underlies the exchange of southern- and northern-sourced water masses, the Argentine margin has not been investigated in detail using scientific drilling techniques, perhaps because the margin has the reputation of being erosional. However, a number of papers published since 2009 have reported new high-resolution and/or multichannel seismic surveys, often combined with multi-beam bathymetric data, which show the common occurrence of layered sediments and prominent sediment drifts on the Argentine and adjacent Uruguayan margins. There has also been significant progress in studying the climatic records in surficial and near-surface sediments recovered in sediment cores from the Argentine margin. Encouraged by these recent results, our 3.5-day IODP (International Ocean Discovery Program) workshop in Buenos Aires (8-11 September 2015) focused on opportunities for scientific drilling on the Atlantic margin of Argentina, which lies beneath a key portion of the global ocean conveyor belt of thermohaline circulation. Significant opportunities exist to study the tectonic evolution, paleoceanography and stratigraphy, sedimentology, and biosphere and geochemistry of this margin.
\end{abstract}




\section{Introduction}

The Argentine Continental Margin (ACM), one of the largest margins worldwide, is a complex geological feature where geotectonic evolution, as well as the post ocean-opening history, configured three types of margins (Fig. 1): passive volcanic rifted (red line), transcurrent (orange line) and mixed convergent, and sheared (yellow line). Apart from its implications for the evolution of the Southern Ocean, the ACM constitutes a key region in the global oceanographic-climatic system as it is the only place in the Southern Ocean with a net water-mass exchange between the equatorial and southern polar regions (Fig. 2). Strong Antarctic-sourced currents run along the Argentine margin, driven by the Coriolis force, from $56^{\circ} \mathrm{S}$ and reaching to at least $34^{\circ} \mathrm{S}$, or even farther north. Also, waters of Northern Hemisphere origin flow south along the Argentine margin north of about $38^{\circ} \mathrm{S}$. The ACM evolution has been affected by climate, current, sea level, and tectonic processes, as well as by sediment input patterns and history along the roughly $5000 \mathrm{~km}$ long coast line of Argentina. All of these characteristics, coupled with the fact that this is a critically important, yet under-sampled portion of the World Ocean, makes the ACM an important region for using IODP (International Ocean Discovery Program) scientific drilling to explore and discover the potential benefits of such operations within the "passive" sector of the margin (here called the Argentine Passive Volcanic Continental Margin - APVCM).

\section{Workshop event, topics, sponsorship and seismic Data}

The IODP workshop event, Developing Scientific Drilling Proposals for the Argentina Passive Volcanic Continental Margin (APVCM) - Basin Evolution, Deep Biosphere, Hydrates, Sediment Dynamics and Ocean Evolution, was held in Buenos Aires on 8-11 September 2015. The 3.5-day event was conducted in the Ministerio de Relaciones Exteriores Comercio Internacional y Culto (Ministry of Foreign Affairs, International Trade and Worship) in the city of Buenos Aires, comprising 45 scientists from 8 countries and 34 organizations or institutions, who discussed scientific drilling on the APVCM (Fig. 1) to determine the composition of and reconstruct the history of the sedimentary deposits under the impact of climatic and tectonic events. Breakout discussion groups were dedicated to tectonics, paleoceanography, sedimentology and seismic stratigraphy, and deep-Earth life forms, biosphere and geochemistry.

The workshop aimed to bring together a diverse group of scientists to explore and discover the merits of and thereby develop a strategy for scientific drilling operations on the APVCM. The goal of a scientific drilling campaign along and across the APVCM is to significantly contribute to our understanding of the evolution of the South Atlantic and its role and influence on global ocean circulation and the climate his-

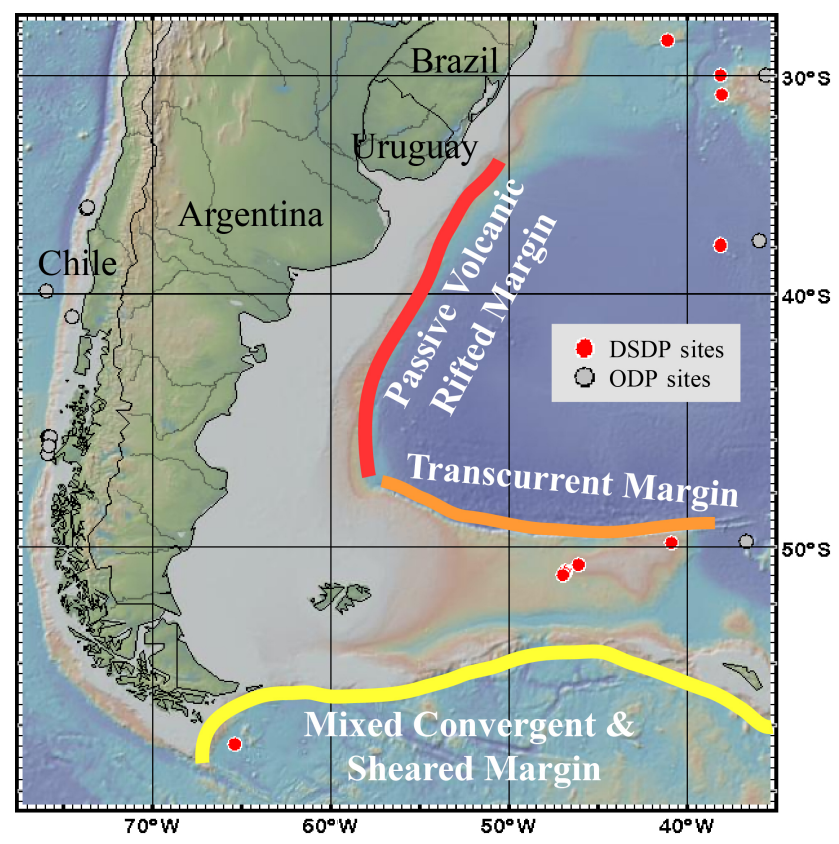

Figure 1. The character of the Argentine Continental Margin. Red: passive volcanic rifted margin; orange: transcurrent margin; yellow: mixed convergent and sheared margin. The passive volcanic rifted margin is termed the APVCM. Red dots indicate DSDP (Deep Sea Drilling Project) sites, gray dots indicate ODP (Ocean Drilling Program) sites. The figure was constructed in GeoMapApp (http: //www.geomapapp.org) using the Global Multi-Resolution Topography (GMRT) synthesis (Ryan et al., 2009).

tory of our planet. Sediments on the APVCM margin range from Late Jurassic-Cretaceous to Holocene in age, and depositional units from approximately the Eocene to Pliocene are particularly well developed. Records from this margin obtained through scientific drilling will be important to resolve key questions of the evolution of Earth's oceans and climate through this period.

IODP workshop topics were introduced to the audience through key note presentations on

- the evolution of the southwestern Atlantic Ocean;

- the structure of the APVCM;

- the nature and timing of rifting and thermal evolution of the margin;

- the nature of sedimentary processes and facies that shaped the margin;

- the margin construction, stability and evolution;

- the climate records, ocean circulation and paleoceanography;

- the history and character of surface and deep circulation along the Argentine margin; 


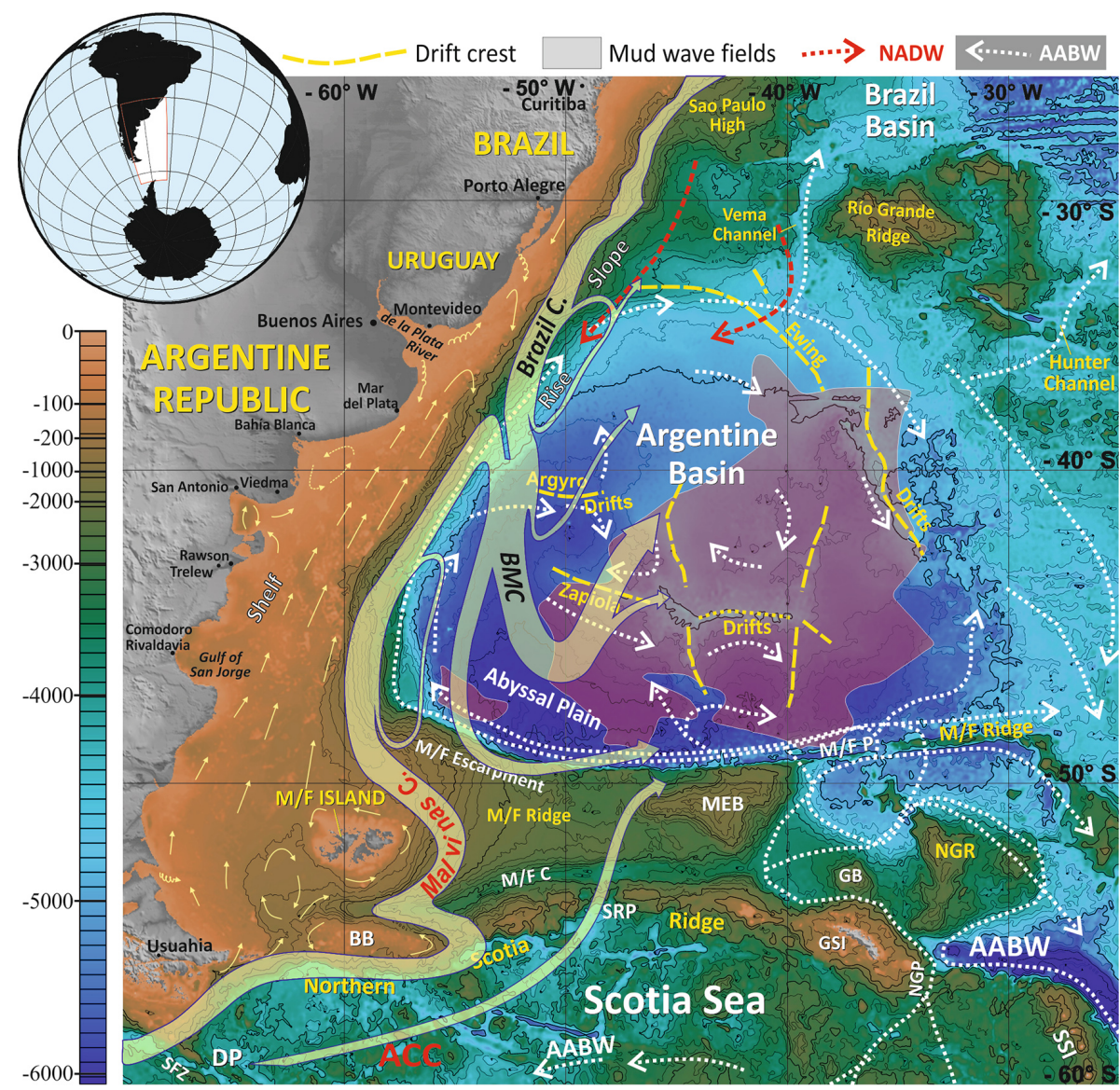

Figure 2. Location of Argentine Basin with regional bathymetric map and general circulation of surface and deep-water masses indicated (after Hernández-Molina et al., 2010). Legend for the physiographic reference points, in alphabetical order: BB: Burdwood Bank; BMC: Brazil-Malvinas Confluence; DP: Drake Passage; M/FI: Malvinas-Falkland Island; M/FE: Malvinas-Falkland Escarpment; M/FP: Malvinas-Falkland Passage; M/FR: Malvinas-Falkland Ridge; GB: Georgia Basin; GP: Georgia Passage; MEB: Maurice Ewing Bank; NGP: Northeast Georgia Passage; NGR: Northeast Georgia Ridge; SG: South Georgia; SFZ: Shackleton Fracture Zone; SRP: Shag Rocks Passage; and SSI: South Sandwich Island. Legend for the water masses: ACC: Antarctic Circumpolar Current; AABW: Antarctic Bottom Water.

- the opportunities for deep biosphere studies on a complex passive margin;

- the data needs for IODP proposals, the capabilities of the R/V JOIDES Resolution and the IODP proposal process.

Workshop sponsorship was provided by the National Science Foundation US Science Support Program (USSSP), Argentina's Ministry of Science, Technology and Productive Innovation (MINCYT-CONICET), the Argentine Ministry of Foreign Affairs, COPLA (National Commission of the Outer Limit of the Shelf - CONVEMAR), the Pampa Azul Initiative, YPF S.A. (Argentina's National Petroleum Company), and CIG (Geological Research Center, University of La Plata - CONICET), Argentina. This was also a European Consortium for Ocean Research Drilling (ECORD) MagellanPlus workshop.

Seismic data are particularly important for planning and executing scientific drilling programs, and for the Argentine margin it is appropriate to mention early on in this report that three significant seismic data sets were shown and discussed at the workshop. The primary data set for the Argentine margin consists of mostly dip lines collected by BGR (Bundesanstalt für Geowissenschaften und Rohstoffe) in Hanover, Germany. The second primary data set consists of the primarily dip seismic lines collected by COPLA, which build on the BGR lines by extending the BGR lines offshore and by filling in between the BGR lines where they are widely spaced. The COPLA lines were collected in support of Argentina's application to set the outer limit of the Argentine continental shelf and there will be limited access to these lines, at least until that process has been concluded. Workshop organizers met with members of COPLA several times before the workshop to discuss the goals of the IODP workshop and the kind of data needed to support IODP scientific drilling. We were told that portions of the lines were expected to be available to support scientific drilling on a case-by-case basis. Indeed, four 


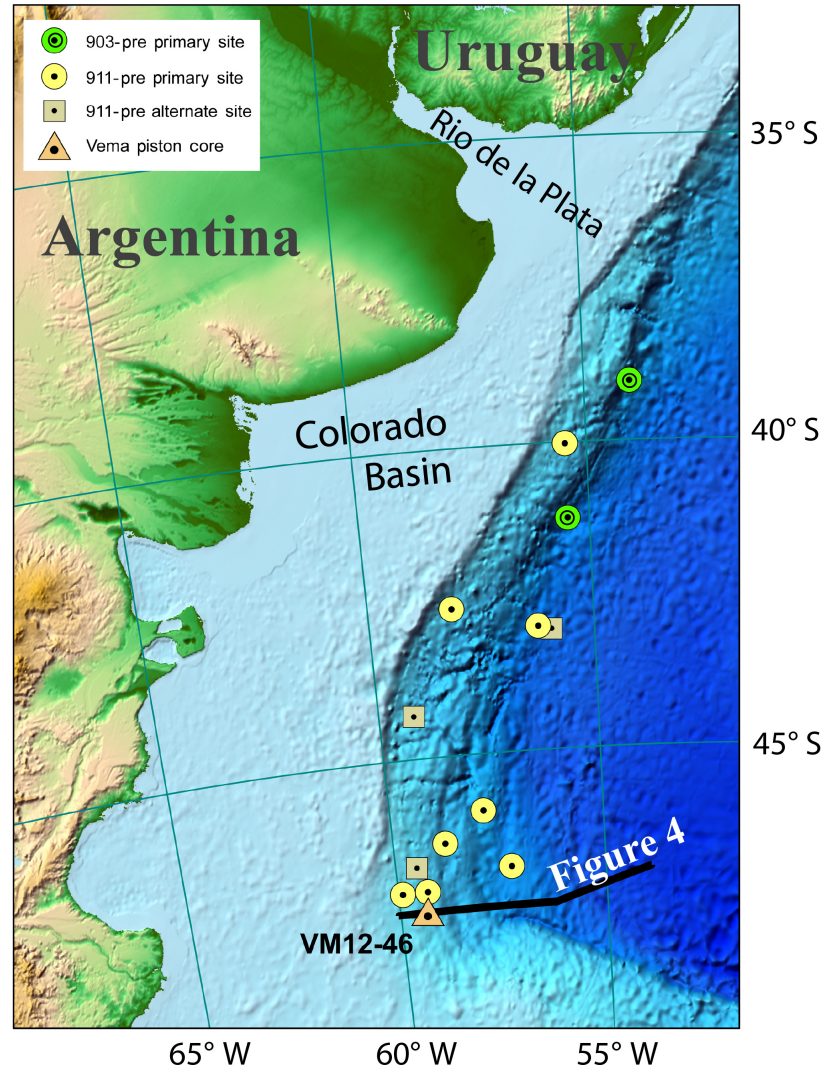

Figure 3. Location of sites proposed by IODP proposals 903-Pre "Argentine margin seaward dipping reflectors" and 911-Pre "Argentine margin paleoceanographic transects". Also shown are the location of core VM12-46 and the location of the seismic profile in Fig. 4. The figure was constructed in ArcMap using the ETOPO1 basemap (http://dx.doi.org/10.7289/V5C8276M).

potential drill sites were proposed during the meeting based on the COPLA lines, and a pre-proposal currently active in the IODP system uses COPLA and BGR lines to define two potential sites (903-Pre, Fig. 3). The ArgentineSPAN-(TM) lines collected on the Argentine margin by ION Geophysical, Inc., were the third set of lines presented and discussed. These deep-penetration, proprietary lines are both strike lines and dip lines, and may also be available to support scientific drilling. Indeed, 911-Pre (Fig. 3) uses ArgentineSPAN-(TM) and BGR lines to define several sites. Other important data sets may exist on the margin, but they were not discussed at this meeting.

\section{Background and geological setting}

The Argentine margin contains important sedimentological, paleontological and chemical records of regional and local tectonic evolution, sea level, climate evolution and ocean circulation that date from the opening of the South Atlantic in the Late Jurassic-Early Cretaceous as well as of the present- day results of post-depositional chemical and biological alteration. Despite its important location, which underlies the exchange of southern- and northern-sourced water masses, the Argentine margin has not been investigated in detail using scientific drilling techniques (Fig. 1). This low level of scientific drilling activity in the region may in part be due to the reports of Maurice Ewing and co-workers (e.g., Lonardi and Ewing, 1971), which, based on widely spaced and lowresolution seismic profiles, noted that the margin had an erosional character as it was crossed by numerous large canyon systems, some of which were likely altered by strong currents. However, a number of papers published since 2009 reported new high-resolution and/or multichannel seismic surveys (Fig. 4), often combined with multi-beam bathymetric data, which show the common occurrence of layered sediments and prominent sediment drifts on the Argentine and adjacent Uruguayan margins (e.g., Hernández-Molina et al., 2009, 2010, 2015; Violante et al., 2010, Krastel et al., 2011; Lastras et al., 2011; Muñoz et al., 2012; Grützner et al., 2011, 2012, 2016; Preu et al., 2012, 2013; Voigt et al., 2013; Uenzelmann-Neben et al., 2016; see also Hinz et al., 1999). There has also been significant progress studying the climatic records in surficial and near-surface sediments recovered in sediment cores from the Argentine margin (e.g., Chiessi et al., 2007; Bozzano et al., 2011; Govin et al., 2012; Bender et al., 2013; Razik et al., 2013; Razik, 2014; García Chapori et al., 2014, 2015), demonstrating that this margin also contains important modern sedimentary deposits.

Encouraged by these recent results, our 3.5-day IODP workshop in Buenos Aires (8-11 September 2015) focused on opportunities for scientific drilling on the APVCM as a significant contribution to several of IODP's research themes described in the program's Science Plan (IODP-SP) for 2013-2023 Illuminating Earth's Past, Present and Future (http://www.iodp.org/program-documents). Future drilling in this region is likely to be of high priority because this margin lies beneath a key portion of the global ocean conveyor belt of thermohaline circulation (Broecker, 1991).

Interest is high in the southern South Atlantic Ocean, and there is currently much being learned about the details of the evolution of this key ocean basin (Torsvik et al., 2009; Moulin et al., 2010; Heine et al., 2013; Granot and Dyment, 2015). The rift phase of the Gondwana breakup extended from the Triassic/Jurassic(?) to the Early Cretaceous. Seaward dipping reflectors (SDRs) are observed on seismic profiles near the continental-ocean boundary (COB), indicating the presence of massive volcanism (a large igneous province, or LIP) at the transition from rifting to drifting (Gladczenko et al., 1997; Hinz et al., 1999). The volcanic layers that make up the SDRs may be subaerial and interbedded with terrestrial sediments. Slumps are observed in the prograding Cretaceous sediment off the Colorado Basin that may thin the sediments over SDRs in some areas. Cretaceous shelf sediments here are expected to be black shales, sandstones and coarser-grained deposits (Loegering et al., 2013) while Cre- 


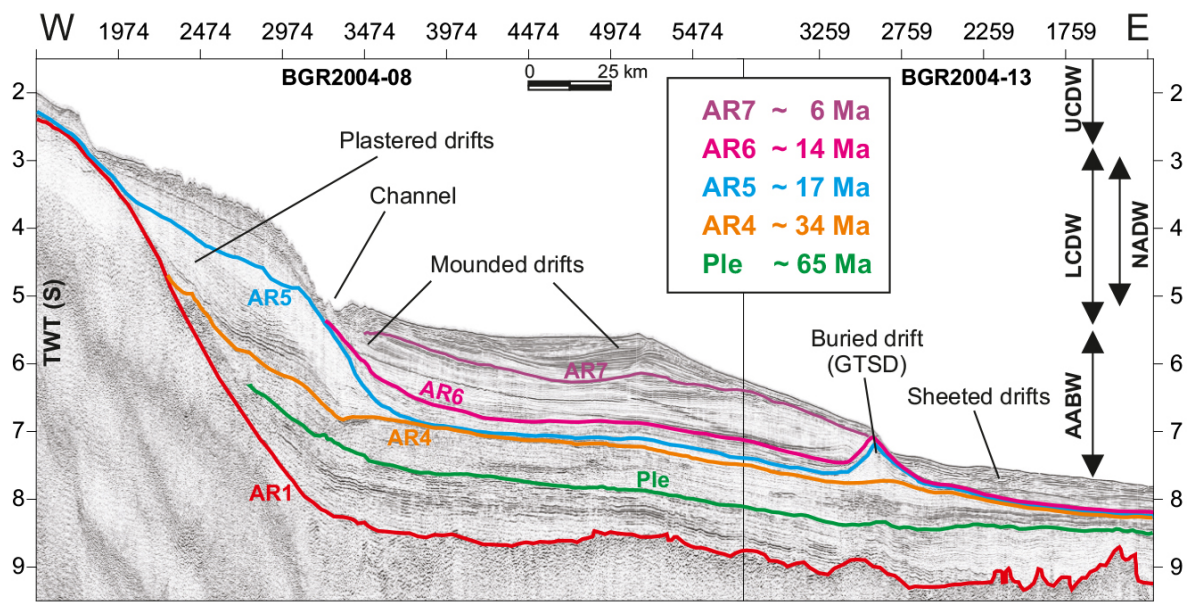

Figure 4. Interpreted seismic line across the Argentine margin featuring distinct drift deposits, channels, and thickness of deposits. Ocean current distribution within the water column: AABW is Antarctic Bottom Water; LCDW is Lower Circumpolar Deep Water; UCDW is Upper Circumpolar Deep Water; NADW is North Atlantic Deep Water (see Grützner et al., 2012). Predicted age and character of the sediment deposits need to be determined through sampling to understand in detail the evolution of the margin in response to climate changes.

taceous sediments in deeper water are likely to be pelagic shales, marls and fine-grained sands (R. Gerster, personal communication, 2015). At about 95 Ma the Equatorial Atlantic Gateway opened, and the gateway continued to enlarge allowing for enhanced exchange of southern waters with the North Atlantic Basin, perhaps leading to a global cooling of bottom water and the end of the Cretaceous greenhouse period (Friedrich et al., 2012; Granot and Dyment, 2015). However, basin-to-basin differences in water properties are not well resolved, including the character of the South Atlantic waters that flooded the North Atlantic Basin (Friedrich et al., 2012).

Hernández-Molina et al. (2010) and Grützner et al. (2012) suggested that sediments from about the Cretaceous-Tertiary boundary to the Eocene-Oligocene boundary are thick along the margin and are characterized by being parallel to subparallel reflections of low to moderate amplitude. This is generally a time of low to moderate bottom current activity and a warm climate.

Lastras et al. (2011) and Muñoz et al. (2012) sampled relatively thick sections of fine-grained Eocene sediments at about 45 to $47^{\circ} \mathrm{S}$ outcropping at water depths of from 900 to $2500 \mathrm{~m}$ in the walls of large canyons. Eocene sediments found in cores from this section of the slope consist of benthic diatoms to the south and a carbonate facies to the north. Ewing and Lonardi (1971) also noted the presence of Eocene sediments in this region of large canyons, as well as canyons on the southern Argentine margin, which may be particularly well developed because they are cut into thick, fine-grained Eocene sediments by persistent, strong currents. Cursory analysis of the ArgentineSPAN-(TM) seismic lines in the area suggest that these layered sediments also exist in somewhat shallower water south of the zone of canyons.
Hanna et al. (1976) and Ross (1976) described several new, non-reworked Eocene diatom species from Vema cores collected in this area. Core VM12-46 $\left(47.483^{\circ} \mathrm{S}, 59.35^{\circ} \mathrm{W}\right.$; water depth $1167 \mathrm{~m})$, described by D. Ericson and available on GeoMapApp (http://www.geomapapp.org), contains a fine-grained Eocene sediment with abundant coccoliths, diatoms, silico-flagellates, radiolarian and sponge spicules as well as common benthic foraminifera.

Eocene sediments on the upper slope are overlain by a prominent but now buried sediment drift in deep water, which is likely of Oligocene to early late Miocene age (Fig. 4; the "giant drift" of Hernández-Molina et al., 2010 and Grützner et al., 2012). This drift is buried to the west by the flanks of younger and shallower deposits (termed "mounded drifts") of mid- to late Miocene age, which developed sequentially within the south-central portion of the Argentine margin. Sediments likely of Pliocene to the Holocene age overlay the mounded drifts, although they are often more localized. These younger sediments are generally interpreted as drifts, perhaps associated with the levees of channels, or deposits within channels, where the channels intersect flow along the margin. Drifts are also present farther north along the margin (e.g., Hernández-Molina et al., 2015) with drifts apparently associated with flows of Antarctic Intermediate Water (AAIW), Upper Circumpolar Deep Water (UCDW), North Atlantic Deep Water (NADW), Lower Circumpolar Deep Water (LCDW) and Antarctic Bottom Water (AABW).

Violante et al. (2010) and Grützner et al. (2011, 2012, 2016) suggested that increased sediment flux to the margin during the Miocene may in part be related to an uplift in the Andes that in turn is due to increased Miocene Pacific Ocean crustal spreading and subduction rates, which peaked at about 10 to $20 \mathrm{Ma}$ (Pardo-Casas and Molnar, 1987; Martinod et al., 2010). However, the routes or processes by which 
Andean sediments reach the margin and are redistributed within the margin are not well understood.

The shift in deposition from primarily shallow-water Eocene sediments to deep-water, drifted Oligocene sediments appears to mark the deepening of the Antarctic Circumpolar Current (ACC) in the Oligocene (Katz et al., 2011) and the first entry of northward-flowing deep waters into the Argentine Basin (Uenzelmann-Neben et al., 2016). The establishment of a shallow ACC in the Eocene played an important role in isolating Antarctica and allowing for the growth of continental ice sheets (Katz et al., 2011), and the thick, shallow-water (now the upper slope) Eocene sediments described along the southern Argentine margin may have accumulated in response to the formation of a shallow ACC and associated shallow northward flow along the Argentine margin. The ACC apparently strengthened and deepened into the Oligocene as the Tasman Gateway and then the Drake Passage deepened, leading to the development of the modern four-layer structure as well as deep northward flow in the Argentine Basin (Katz et al., 2011; Figs. 2 and 4).

The mid-late Miocene is a particularly important time in terms of climate history and global ocean circulation. During the early Miocene, the Antarctic Ice Sheet (AIS) appears to have fluctuated in size, with concomitant changes in sea level of about $\pm 20 \mathrm{~m}$ (e.g., Foster et al., 2012). The mid-Miocene was characterized by the mid-Miocene Climatic Optimum (MCO), which extends from about 17 to $15 \mathrm{Ma}$. This was a time of reduced AIS volume $(\sim 10-25 \%$ of the modern AIS), high $p \mathrm{CO}_{2}$ (up to $\sim 450 \mathrm{ppm}$ ) and global temperatures warmer than today. Following the MCO, more complex oceanic circulation patterns developed during the midMiocene Climatic Transition (MMCT) from about 14.2 to 13.8 Ma. Possible important events that occurred at that time include the emplacement of large volcanic complexes (such as the Columbia River Basalts, CRB), which would have affected $p \mathrm{CO}_{2}$ (Armstrong McKay et al., 2014), the Andean uplift with an impact on atmospheric circulation and weathering patterns (Violante et al., 2010; Grützner et al., 2011 and 2012), and the closing of the Tethys seaway, which changed global ocean circulation patterns (Hamon et al., 2013). Climate deterioration continued into the late Miocene, leading to the initiation and growth of the West Antarctic Ice Sheet (Shevenell et al., 2004). Climatic deterioration has continued into the Pleistocene although the major current systems that were established between the end of the Miocene and the late Pliocene appear to have continued to the present day (Hernández-Molina et al., 2009; Preu et al., 2012, 2013). However, factors other than ocean currents have also been important to the development of the margin, including sea level change, climate variability and glaciation and uplift in the Andes (Violante et al., 2010; Grützner et al., 2011 and 2012). These kinds of factors can also control the timing, locations and rates of sediment input, which can also affect margin evolution.
4 Drilling to investigate the tectonic, paleoceanographic, sedimentation, and biosphere history of the APVCM - recommendations from the workshop

Workshop participants agreed that scientific ocean drilling off Argentina (both in deep and shallow water) will contribute to the understanding of the role that the southern region has played in climate evolution and associated processes and will provide opportunities for focused studies.

The APVCM provides outstanding targets for investigating sedimentation and paleoceanographic conditions from the Cretaceous to the Holocene. The unique setting in the target region is linked to the tectonic evolution of Antarctica, the Southern and South Atlantic oceans, and the Andes. Specific questions and hypotheses were discussed in groups regarding several main sub-topics.

\subsection{Tectonic evolution}

One sub-topic discussion group was focused on developing a strategy to identify targets that highlight the opening of the South Atlantic and allow for testing the various models for the breakup of Gondwana and emplacement of shear zones, for example as expressions of transcurrent boundaries. SDRs and associated magnetic/gravity anomalies are important volcanic and geophysical features that can constrain geotectonic models of the opening of the South Atlantic and the evolution of its margins. We need to better understand the structure, fragmentation and thermal evolution of SDRs, which can be identified in seismic lines. We need to collect in situ samples for age dating and we need to determine the likely depths of events related to SDR emplacement and evolution. We also need to better characterize the geochemical composition and mineralogy of the SDR layers to better perceive their emplacement and thermal evolution. Drilling and sampling the SDRs of the Argentina Basin (deep-water realm of the APVCM) will allow us to address the following scientific objectives related to challenges 8, 9 and 10 of the Earth connections theme in the IODP Science Plan for 2013-2023 (IODP-SP):

- What is the age and composition of the SDRs?

- What was the source of magma (asthenosphere vs. deep mantle plumes) for the initial melts emplaced during the early opening of the South Atlantic, and what does this tell us about models of continental rifting/fragmentation?

- What was the nature of magma and continental crust interactions during SDR emplacement, and what does this indicate about crustal anatexis, crustal lithology, and composition of gases delivered to the ocean and/or atmosphere during emplacement? 
- How has the structural, tectonic and thermal evolution of the margin influenced the both large-scale and local sedimentation patterns on the margin over time?

\subsection{Paleoceanography and stratigraphy}

This sub-group engaged in a discussion of the opening of the South Atlantic and how the changing configuration of the ocean basins and distribution of landmasses affected the evolution of the ocean and climate. Since the age of the APVCM allows one (in theory) to tap into sediments back as far as the mid-Late Cretaceous, it may be possible to sample sediments that record the successive oceanic-anoxic events (OAEs) that occurred during the mid-Cretaceous " $\mathrm{Su}$ per Greenhouse" (Aptian-Turonian), a time with characteristically high atmospheric $\mathrm{CO}_{2}$ concentrations and very warm deep-ocean and polar surface temperatures. These kinds of records from this region (and time period) exist (e.g., DSDP (Deep Sea Drilling Project) sites 327, 511) but they are limited with enigmatic findings. The stratigraphic evolution of the Argentine Basin during the Eocene through to the present day, as demonstrated in seismic profiles, and its relationship to the global ocean conveyor belt circulation and paleoclimate at that time and forward into modern times, is far from understood. While many key circulation events are interpreted from layering patterns on seismic profiles, the origin of the seismic layering and the ages of significant seismic reflections are yet to be directly determined. This is an important step in order to fully exploit the seismic signature of margin evolution. However, it is likely that sediment records obtained from this margin (from both shallow and deep water) will provide important and possibly expanded and continuous sequences for detailed biostratigraphic and magnetostratigraphic studies during important time periods. Analysis of these records can help to illuminate questions relevant to challenges 1 and 4 of IODP-SP's climate and ocean change theme such as

- When did marine sedimentation begin, how rapidly did the South Atlantic deepen and when did northernsourced water impact this region?

- How are Cretaceous OAEs expressed in this area and does this expression change as the South Atlantic widened and deepened during the Late Cretaceous? What is the importance of circulation changes vs. productivity in the formation of OAEs?

- What was the nature of the deep-water mass in the South Atlantic during the Late Cretaceous "Super Greenhouse"? At what point is there evidence for a significant contribution from southern-sourced (Antarctic) deep water?

- Can depth transects of sites representing different times in the evolution of the South Atlantic circulation be found at different latitudes along the margin to determine the spatial and temporal evolution of circulation along the margin?

- Can scientific drilling help to further decipher the peculiar and significant impact of the Miocene on the atmospheric evolution of our planet? How was the Neogene shaped globally through processes taking place on or recorded in sediments of the APVCM?

\subsection{Sedimentology}

This sub-group considered the sediment record from a somewhat different perspective than the "Paleoceanography and sedimentology" topic, and questions were raised related to links between climate, sediment accumulation, atmospheric circulation and the Andean orogeny, which is the most prominent tectonic feature in the Southern Hemisphere (Ghiglione et al., 2016). One particular example is that records from the continental margin will extend and complement records of wind-blown sediments recovered from Argentine loess deposits and Patagonian lakes (Heil Jr. et al., 2010; Lisé-Pronovost et al., 2015). These kinds of topics pertain to IODP-SP's climate and ocean change theme challenges 1 and 3:

- Does a signal of Andean orogeny exist in the sedimentary record of the Argentine margin? If so, what does it look like and how should it be interpreted?

- Can we identify connections between paleo-climate and sedimentation patterns and rates in the region?

- Did processes in this region have an impact on global sedimentation rates and patterns?

- Can we identify and track material in a "source-to-sink" framework from the Andes to the Argentine margin as well as to the various basins?

- How did Andean tectonics affect the global ocean and atmospheric circulation (wind) patterns and conditions?

- Has Andean dust/loess affected primary bioproductivity during the Neogene, and might that signal also be reflected in $\mathrm{CO}_{2}$ uptake/release signatures imprinted in the sediment deposits?

- What can we learn about how Andean volcanism evolved and how those volcanic process and the record of uplift and erosion help us understand the subduction processes here?

- What can the sediment recorded in margin sediments tell us about temporal variability of the sources of material to the margin and in the nature of along-slope and across-slope transport processes? 


\subsection{Biosphere and geochemistry}

This sub-group was focused on discussing the variable presence, quality and quantity of organic matter along the APVCM, because reactions related to organic matter decomposition provide the energy needed by subsurface biosphere communities. In many areas microbial life and the cycling of elements is studied in steady-state environments while seismic profiles from the Argentine margin demonstrate a dynamic sedimentary environment. The APVCM is thereby considered and treated as a temporal and spatial non-steadystate depositional system, which is highly impacted by complex and dynamic sediment reworking processes (Hensen et al., 2003; Riedinger et al., 2014; Razik, 2014). Gravitydriven sediment deposition, sea level variations, strong currents and complex paleo-productivities across the short-tolong-term timescales are all contributing factors to generating complex geochemical cycling and biosphere activity. Buried organic-rich layers can be re-activated under certain temperature and pressure changes, thus providing food for subsurface microbial communities. Organic substrates can diffuse into adjacent, often organic-lean, sediment layers, and this new energy source can cause strong alteration of the sedimentary record long after deposition. Since little data exist for a non-steady-state sediment depositional system along and across a passive margin, the APVCM represents a perfect playground to examine the diversity and activity of subsurface microbial communities and their responses to dynamic changes in their sedimentary environment. Geomicrobiological and bio-geochemical (in conjunction with detailed physical-property) studies in such deposits could be pursued with a modest addition of the appropriate shipboard personnel and relates to challenges 5 and 7 of IODP-SP's biosphere frontiers theme:

- How does the diversity and activity of microbial life vary with depth, geochemistry, and sediment composition and age across the APVCM?

- Furthermore, does microbial activity change with nonsteady-state sedimentation?

- How do the amounts and fluxes of carbon change in time and space across the APVCM in relation to variations in primary external parameters? Are carbon and nutrients preferentially stored in sediment during times of rapid sediment accumulation and returned to the ocean during times of slow sedimentation? How does that affect the $\mathrm{CO}_{2}$ input/release from the sediments?

\section{Augmenting data and data management methods}

Development of APVCM-specific drilling proposals to address the objectives cited above will require the acquisition of additional data sets. Specifically, the following was suggested during the workshop:
Priority no. 1: obtain additional seismic data sets, including cross-lines to complement existing seismic data, for possible target sites. Such new seismic lines should be acquired using methods that resolve deeper sedimentary structures in addition to the upper sedimentary sequences. These data can be used to develop several drilling transects at different latitudes to target the collection of important Paleogene and Neogene sequences as well as to support drilling to deeper targets such as SDRs and Mesozoic sediments.

Action no. 1: augment existing high-quality seismic data (e.g., Grützner et al., 2012), for example through GEOMAR's three-dimensional (3-D) P-Cable (Planke et al., 2009; Planke and Berndt, 2002) and/or using other seismic systems, such as provided through the U.S. National Science Foundation (NSF) or other research grants.

Action no. 2: evaluate existing sediment samples and collect new gravity and piston cores near potential drill sites to document the age, nature and character of the near-surface material to support the potential transect-oriented IODP proposals.

Priority no. 2: coordinate with Pampa Azul, a strategic project of scientific research along the Argentine margin supported by the Argentine state (http://en.mincyt.gob.ar/accion/ pampa-azul-9465). As stated on the Pampa Azul web site, the main objective of Pampa Azul is to help deepen scientific knowledge as the basis of conservation policies and management of natural resources, promote technological innovations applicable to the sustainable exploitation of natural resources and the development of industries related to the sea, strengthen the maritime awareness of Argentine society and support with scientific information and presence the country's sovereignty in the South Atlantic area. The Pampa Azul initiative was a one of the workshop sponsors and several of the attendees were associated with Pampa Azul. We encourage linkages between any scientific drilling campaign on the APVCM and Pampa Azul investigators. Argentina provides an excellent example for developing a vibrant, highly ambitious ocean research program (Pampa Azul). Coordinating with Pampa Azul through this IODP-sponsored workshop provided an important mechanism to begin important collaborations between the Argentine ocean research community and IODP investigators.

Priority no. 3: encourage the development of continentocean transect drilling proposals for joint evaluation by IODP and ICDP (International Continental Scientific Drilling Program). Important and complementary records come from both continental and marine settings, and a full understanding of margin evolution and requires working in both settings.

\section{Outcomes of the workshop}

The main outcome of this workshop is the formation of several working groups addressing the various scientific top- 
ics briefly outlined in this report, and committed to preparing several pre-/full proposals to IODP that are appropriate for the R/V JOIDES resolution. As of January, 2017 two preliminary proposals are active in the IODP system and full proposals for these proposals have been invited; see https://www.iodp.org/proposals/active-proposals for full details. The 903-Pre "Argentine margin seaward dipping reflectors" considers the early opening of the South Atlantic and especially the sampling of the SDRs that formed in a nonhotspot setting and the overlying Cretaceous and Cenozoic sediments. Secondary objectives include the evolution of atmospheric circulation and the diversity and activity of microbial life under non-steady-state conditions. 911-Pre "Argentine margin paleoceanographic transects" develops a "transect" approach to better understand the evolution of Southern Ocean water structure over a broad vertical and temporal range. Secondary objectives include how the passive margin architecture responds to Cenozoic climate and tectonics and the microbial variability through time under different climate, deep-water circulation and sediment-flux regimes. Developing these and other pre-/full proposals for the time window when the R/V JOIDES resolution is likely to operate in the South Atlantic will probably require the collection of additional data and coordination amongst the international partners.

\section{Relationship to IODP Science Plan for 2013-2023 and beyond}

The scientific objectives for potential IODP drilling proposals are central aspects of the International Ocean Discovery Program as formulated in the Science Plan for 2013-2023 Illuminating Earth's Past, Present, and Future. Knowledge acquired as a result of this drilling project will significantly advance the IODP theme "climate and ocean change: reading the past, informing the future", specifically challenges 1 "how does Earth's climate system respond to elevated levels of atmospheric $\mathrm{CO}_{2}$ ?", 3 "what controls regional patterns of precipitation, such as those associated with monsoons or El Niño?" and 4 "how resilient is the ocean to chemical perturbations?", as well as the "Earth connections: deep processes and their impact on Earth's surface environment" theme, specifically challenges 8 "what are the composition, structure, and dynamics of Earth's upper mantle?", 9 "how are seafloor spreading and mantle melting linked to ocean crustal architecture?", and 10 "what are the mechanisms, magnitude, and history of chemical exchanges between the oceanic crust and seawater?" Throughout the workshop we have been learning how to integrate objectives related to biosphere frontiers with those of other themes. This has been very successful and drilling resulting from this workshop will significantly advance the IODP theme "biosphere frontiers: deep life, biodiversity, and environmental forcing of ecosystems", specifically challenges 5 "what are the origin, compo- sition and global significance of subseafloor communities" and 7 "how sensitive are ecosystems and biodiversity to environmental change?"

\section{Societal relevance and responsibility}

The interconnection of this IODP project with Pampa Azul and corresponding initiatives (for example with the German DFG-BMBF) provides opportunities for early-career scientists among the various countries. ICDP at the German Research Centre for Geosciences (GFZ) in Potsdam actively fosters and sponsors such efforts and incentives via financial and logistical support. We also encourage syndicated, perhaps educational television, documentaries about scientific drilling on the Argentine margin as projects develop. This type of activity can help to inform the general public, whose tax dollars finance these studies, and raise favorable awareness for these types of international collaborations at a time of significant geo-political and economic challenges. This is just one aspect of interacting with the public at all levels in order to generate a deeper understanding and appreciation for the importance of scientific drilling both on land and in the ocean.

\section{Conclusions}

The evolution of the Argentine Continental Margin has been affected by climate, current, sea level and tectonic processes, as well as by sediment input patterns and depositional history along this roughly $5000 \mathrm{~km}$ long coast line. All of these characteristics, coupled with the fact that this is a critically important, yet under-sampled, portion of the World Ocean, makes the Argentine Continental Margin an important region for IODP scientific drilling. Workshop participants agreed that scientific ocean drilling off Argentina will contribute to the understanding of the role that the southern region has played in climate evolution and associated processes and will provide opportunities for focused studies. The APVCM provides outstanding targets for investigating sedimentation patterns, climatic, paleo-circulation and paleoceanographic conditions, biosphere and geochemistry from the Cretaceous to the Holocene. The evolution of this important setting is also linked to the evolution of the World Ocean as well as to the tectonic evolution of Antarctica, the Southern and South Atlantic oceans, and the Andes.

Author contributions. Report authors consist of the workshop steering committee.

Competing interests. Authors Roberto A. Violante, Thomas Gorgas, Ernesto Schwarz, Jens Grützner, Gabriele UenzelmannNeben and F. Javier Hernández-Molina are proponents of IODP scientific drilling proposals 903-Pre and/or 911-Pre. 
Table 1. IODP workshop: developing scientific drilling proposals for the Argentina Passive Volcanic Continental Margin (APVCM) - basin evolution, deep biosphere, hydrates, sediment dynamics and ocean evolution.

\begin{tabular}{|c|c|c|}
\hline \multicolumn{3}{|c|}{ Workshop participants, Buenos Aires, 8-11 September 2015} \\
\hline Name & Institution & E-mail \\
\hline Ariztegui, Daniel & University of Geneva, Switzerland & daniel.ariztegui@unige.ch \\
\hline Beilinson, Elisa & CIG - UNLP, Argentina & beilinson@cig.museo.unlp.edu.ar \\
\hline Berndt, Christian & Christian-Albrechts-University, Germany & cberndt@geomar.de \\
\hline Bolatti, Nestor & YPF - Offshore, Argentina & nestor.bolatti@ypf.com \\
\hline Bozzano, Graziella & Servicio de Hidrografía Naval, Argentina & grazi.hidro.gov.ar@gmail.com \\
\hline Briggs, Brandon & University of Alaska - Anchorage, USA & bbriggs@uaa.alaska.edu \\
\hline Cuitiño, José & CENPAT - CONICET, Argentina & jcuitino@cenpat-conicet.gob.ar \\
\hline Dickens, Gerald & Rice University, USA & jerry@ rice.edu \\
\hline Esteban, Federico & IGeBA - UBA, Argentina & federico.esteban@gmail.com \\
\hline Flood, Roger & Stony Brook University, USA & roger.flood@stonybrook.edu \\
\hline Garcia Chapori, Natalia & SACMa - IDEAN - UBA, Argentina & nataliag@gl.fcen.uba.ar \\
\hline Gerster, Ricardo & YPF - Offshore, Argentina & ricardo.gerster@ypf.com \\
\hline Ghidella, Marta & Instituto Antartico Argentino, Argentina & mghidella@gmail.com \\
\hline Gomez, Fernando & CICTERRA Córdoba, CONICET, Argentina & fernandogomez411@gmail.com \\
\hline Gorgas, Thomas & GFZ, Potsdam, Germany & tgorgas@gfz-potsdam.de \\
\hline Gruetzner, Jens & Alfred-Wegener-Institut, Germany & jens.gruetzner@awi.de \\
\hline Heil, Chip & University of Rhode Island, USA & chiph@uri.edu \\
\hline Hernández-Molina, F. Javier & Royal Holloway University, London, UK & javier.hernandez-molina@rhul.ac.uk \\
\hline Iglesia Llanos, Paula & IGeBA - UBA, Argentina & mpiglesia@gl.fcen.uba.ar \\
\hline Isola, José & IGeBA - UBA, Argentina & jose.isola91@gmail.com \\
\hline Jimenez, Mariano & Urien \& Assoc., Argentina & mariano_registrado@hotmail.com \\
\hline Kress, Pedro R. & YPF - Offshore, Argentina & pkress@ypf.com \\
\hline Kulhanek, Denise & IODP-JRSO-TAMU JRSO, USA & kulhanek@iodp.tamu.edu \\
\hline Leon Zayas, Rosa & University of Delaware, USA & rleonzay@udel.edu \\
\hline Malumian, Norberto & CONICET, Argentina & n.malumian@yahoo.com \\
\hline Medina Ketze, Joao Marcelor & Instituto do Petróleo e Recursos Naturais, PUCRS, Brazil & jketzer@pucrs.br \\
\hline Orgeira, Maria Julia & CONICET - UBA, Argentina & orgeira@gl.fcen.uba.ar \\
\hline Paterlini, C. Marcelo & COPLA - Servicio de Hidrografía Naval, Argentina & cmpaterlini@yahoo.com.ar \\
\hline Perez Panera, Juan P. & Y-Tec, Argentina & perezpanera@gmail.com \\
\hline Ramos, Victor & UBA - CONICET, Argentina & andes@gl.fcen.uba.ar \\
\hline Rapalini, Augusto & IGeBA - UBA - CONICET, Argentina & rapalini@gl.fcen.uba.ar \\
\hline Reuber, Kyle & University of Houston \& ION - GeoVentures, USA & kyle.reuber@iongeo.com \\
\hline Riedinger, Natascha & Oklahoma State University, USA & natascha.riedinger@okstate.edu \\
\hline Schwarz, Ernesto & CIG - UNLP - CONICET, Argentina & eschwarz@cig.museo.unlp.edu.ar \\
\hline Selva, Carlos & Y-Tec, Argentina & carlos.selva@ypf.com \\
\hline Slowey, Niall & Dept of Oceanography, TAMU, USA & slowey@geos.tamu.edu \\
\hline Soto, Matías & ANCAP Uruguay & msoto@fcien.edu.uy \\
\hline St-Onge, Guillaume & Université du Québec à Rimouski, Canada & guillaume_st-onge@uqar.ca \\
\hline Tassone, Alejandro & IGeBA - UBA - CONICET. Pampa Azul, Argentina & atassone@gl.fcen.uba.ar \\
\hline Troisi, Ariel & Servicio de Hidrografía Naval, Argentina & atroisi@hidro.gov.ar \\
\hline Uenzelmann-Neben, Gabriele & Alfred-Wegener-Institut, Germany & gabriele.uenzelmann-neben@awi.de \\
\hline Urien, Carlos Maria & Urien \& Assoc., Argentina & uriencm@fibertel.com.ar \\
\hline Violante, Roberto A. & Servicio de Hidrografía Naval. Pampa Azul, Argentina & rober.a.violante@gmail.com \\
\hline Wehrmann, Laura & Stony Brook University, USA & laura.wehrmann@stonybrook.edu \\
\hline Wright, Jim & Rutgers University, USA & jdwright@rci.rutgers.edu \\
\hline
\end{tabular}


Acknowledgements. We thank NSF-USSSP, ECORD/ICDP, COPLA, Ministry of Foreign Office, Ministry of Science (MINCYT), Pampa Azul, YPF, Y-Tec, IGeBA, CIG-CONICET-UNLP, the German IODP Koordinationsbüro, the Pontifical Catholic University of Rio Grande do Sul, Brazil, and ANCAP for generously providing logistical and financial support for the APVCM workshop and event attendees. COPLA Coordinator Frida Armas Pfirter and Minister Osvaldo Mársico deserve special thanks for their hospitality and for doing a superb job hosting this event (which received rave reviews from the attendees) in concert with a competent technical service team at the venue. Supporting Institutions in Argentina were the Argentina Hydrographic Survey and the Instituto de Geologia de Costas y del Cuaternario-University of Mar del Plata. Research was conducted in the framework of the "Drifters" Research Group of the Royal Holloway University of London. We appreciate the constructive feedback from various reviewers of the original workshop proposal, in particular Ann Holbourn (Kiel University), and also the reviewers of this workshop report. We especially acknowledge Manika Prasad, Christian Berndt and, in particular, Denise Kulhanek (IODP-JRSO-TAMU) and Jim Wright (Rutgers), who led efforts to submit the first two APVCM pre-proposals (903-Pre and 911-Pre). Most importantly, thanks go to all workshop attendees and participating scientists for their enthusiastic and ongoing contributions before, during and after the event, thereby helping to develop pre-proposals as concrete outcomes from this workshop. All investigators, workshop attendees and updates can be found on the ICDP project website at http://apvcm.icdp-online.org. Additional details can also be found at http://usoceandiscovery.org/workshops/. Contribution no. 1434 of the School of Marine and Atmospheric Sciences, Stony Brook University.

Edited by: J. Behrmann

Reviewed by: two anonymous referees

\section{References}

Armstrong McKay, D. I., Tyrrell, T., Wilson, P. A., and Foster, G. L.: Estimating the impact of the cryptic degassing of Large Igneous Provinces: A mid-Miocene case-study. Earth and Sciences Letters, 403, 254-262, doi:10.1016/j.epsl.2014.06.040, 2014.

Bender, V. B., Hanebuth, T. J. J., and Chiessi, C. M.: Holocene shifts of the Subtropical Shelf Front off southeastern South America controlled by high and low latitude atmospheric forcings, Paleoceanography, 28, 481-490, doi:10.1002/palo.20044, 2013.

Bozzano, G., Violante, R. A., and Cerredo, M. E.: Middle slope contourite deposits and associated sedimentary facies off NE Argentina, Geo-Mar. Lett., 31, 495-507, doi:10.1007/s00367-0110239-x, 2011

Broecker, W.: The great ocean conveyor, Oceanography, 4, 79-89, doi:10.5670/oceanog.1991.07, 1991.

Chiessi, C. M., Ulrich, S., Mulitza, S., Pätzold, J., and Wefer, G.: Signature of the Brazil-Malvinas Confluence (Argentine Basin) in the isotopic composition of planktonic foraminifera from surface sediments, Mar. Micropaleontol., 64, 52-66, doi:10.1016/j.marmicro.2007.02.002, 2007.

Ewing, M. and Lonardi, A. G.: Sediment transport and deposition in the Argentine Basin. 5. Sedimentary structures of the Argentine margin, basin and related provinces, Phys. Chem. Earth, 8, 125156, doi:10.1016/0079-1946(71)90017-6, 1971.

Foster, G. L., Lear, C. H., and Rae, J. W. B.: The evolution of $\mathrm{pCO}_{2}$, ice volume and climate during the middle Miocene, Earth Planet Sc. Lett., 341-344, 243-254, doi:10.1016/j.epsl.2012.06.007, 2012.

Friedrich, O., Norris, R. D., and Erbacher, J.: Evolution of middle to Late Cretaceous oceans - A 55 m.y. record of Earth's temperature and carbon cycle, Geology, 40, 107-110, doi:10.1130/G32701.1, 2012.

García Chapori, N., Laprida, C., Watanabe, S., Totah, V., and Violante, R. A.: Mid-Late Pleistocene benthic foraminifera from Southwestern South Atlantic: driven by primary productivity or watermass properties?, Micropaleontology, 60, 195-210, 2014.

García Chapori, N., Chiessi, C. M., Bickert, T., and Laprida, C.: Sea-surface temperature reconstruction of the Quaternary western South Atlantic: New planktonic foraminiferal correlation function, Palaeogeogr. Palaeocl., 425, 67-75, doi:10.1016/j.palaeo.2015.02.027, 2015.

Ghiglione, M. C., Sue, C., Ramos, M., Tobal, J. E., and Gallardo, R. E.: The Relation Between Neogene Denudation of the Southernmost Andes and Sedimentation in the Offshore Argentine and Malvinas Basins During the Opening of the Drake Passage. Chapter 5 in: Geodynamic Evolution of the Southernmost Andes, edited by: Ghiglione, M. C., 206 pp., ISBN: 978-3-31939727-6, 2016.

Gladczenko, T. P., Hinz, K., Eldholm, O., Meyer, H., Neben, S., and Skogseid, J.: South Atlantic volcanic margins, J. Geol Soc. London, 154, 465-470, doi:10.1144/gsjgs.154.3.0465, 1997.

Govin, A., Holzwarth, U., Heslop, D., Ford Keeling, L., Zabel, M., Mulitza, S., Collins, J. A., and Chiessi, C. M.: Distribution of major elements in Atlantic surface sediments $\left(36 \mathrm{~N}^{\circ}-49^{\circ} \mathrm{S}\right)$ : Imprints of terrigenous input and continental weathering, Geochem. Geophy. Geosy., 13, Q01013, doi:10.1029/2011GC003785, 2012.

Granot, R. and Dyment, J.: The Cretaceous opening of the South Atlantic Ocean, EPSL, 414, 156-163, doi:10.1016/j.eps1.2015.01.015, 2015.

Grützner, J., Uenzelmann-Neben, G., and Franke, D.: Variations in bottom water activity at the southern Argentine margin: indications from a seismic analysis of a continental slope terrace, GeoMar. Lett, 31, 405-417, doi:10.1007/s00367-011-0252-0, 2011.

Grützner, J., Uenzelmann-Neben, G., and Franke, D.: Variations in sediment transport at the central Argentine continental margin during the Cenozoic, Geochem. Geophy. Geosy., 13, Q10003, doi:10.1029/2012GC004266, 2012.

Grützner, J., Uenzelmann-Neben, G., and Franke, D.: Evolution of the northern Argentine margin during the Cenozoic controlled by bottom current dynamics and gravitational processes, Geochem. Geophy. Geosy., 17, 3131-3149, doi:10.1002/2015GC006232, 2016.

Hamon, N., Sepulchre, P., Lefebvre, V., and Ramstein, G.: The role of eastern Tethys seaway closure in the Middle Miocene Climatic Transition (ca. 14 Ma), Clim. Past, 9, 2687-2702, doi:10.5194/cp-9-2687-2013, 2013.

Hanna, G. D., Hendey, I. N., and Brigger, A. L.: Some Eocene diatoms from South Atlantic cores, Part I. California Academy of Sciences, Occ. Papers, 123, 1-19, 1976. 
Heil Jr., C. W., King, J. W., Zarate, M., and Schultz, P. H.: Climatic interpretation of 1.9 Ma environmental magnetic record of loess deposition and soil formation in the central eastern Pampas of Buenos Aires, Argentina, Quaternary Sci. Rev., 29, 2705-2718, doi:10.1016/j.quascirev.2010.06.024, 2010.

Heine, C., Zoethout, J., and Müller, R. D.: Kinematics of the South Atlantic rift, Solid Earth, 4, 215-253, doi:10.5194/se-4215-2013, 2013.

Hensen, C., Zabel, M., Pfeifer, K., Schwenk, T., Kasten, S., Riedinger, N., Schulz, H. D., and Boetius, A.: Control of sulfate pore-water profiles by sedimentary events and the significance of anaerobic oxidation of methane for burial of sulfur in marine sediments, Geochim. Cosmochim. Ac., 67, 2631-2647, doi:10.1016/S0016-7037(03)00199-6, 2003.

Hernández-Molina, F. J., Paterlini, M., Violante, R., Marshall, P., de Isasi, M., Somoza, L., and Rebesco, M.: Contourite depositional system on the Argentine Slope: An exceptional record of the influence of Antarctic water masses, Geology, 37, 507-510, doi:10.1130/G25578A.1, 2009.

Hernández-Molina, F. J., Paterlini, M., Somoza, L., Violante, R., Arecco, M. A., de Isasi, M., Rebesco, M., Uenzelmann-Neben, G., Neben, S., and Marshall, P.: Giant mounded drifts in the Argentine Continental Margin: Origins and global implications for the history of thermohaline circulation. Mar. Petrol. Geol., 27, 1508-1530, doi:10.1016/j.marpetgeo.2010.04.003, 2010.

Hernández-Molina, F. J., Soto, M., Piola, A. R., Tomasini, J., Preu, B., Thompson, P., Badalini, G., Creaser, A., Violante, R., Morales, E., and de Santa Ana, H.: A contourite depositional system along the Uruguyan continental margin: Sedimentary, oceanographic and paleocenographic implications, Mar. Geol., 378, 333-349, doi:10.1016/j.margeo.2015.10.008, 2015.

Hinz, K., Neben, S., Schreckenberger, B., Roeser, H. A., Block, M., Gonçalves de Souza, K., and Meyer, H.: The Argentine continental margin north of $48^{\circ} \mathrm{S}$ : Sedimentary successions, volcanic activity during breakup Mar. Petrol. Geol., 16, 1-25, doi:10.1016/S0264-8172(98)00060-9, 1999.

Katz, M. E., Cramer, B. S., Toggweiler, J. R., Esmay, G., Liu, C., Miller, K. G., Rosenthal, Y., Wade, B. S., and Wright, J. D.: Impact of Antarctic Circumpolar Current development on Late Paleogene ocean structure, Science, 332, 1076-1079, doi:10.1126/science.1202122, 2011.

Krastel, S., Wefer, G., Hanebuth, T. J. J., Antobreh, A. A., Freudenthal, T., Preu, B., Schwenk, T., Strasser, M., Violante, R., and Winkelmann, D.: Sediment dynamics and geohazards off Uruguay and the de la Plata region (northern Argentina and Uruguay), Geo-Mar. Lett., 31, 271-283, doi:10.1007/s00367011-0232-4, 2011.

Lastras, G., Acosta, J., Muñoz, A., and Canals, M.: Submarine canyon formation and evolution in the Argentine Continental Margin between $44^{\circ} 30^{\prime} \mathrm{S}$ and $48^{\circ} \mathrm{S}$, Geomorphology, 128, 116136, doi:10.1016/j.geomorph.2010.12.027, 2011.

Lisé-Pronovost, A., St-Onge, G., Gogorza, C., Haberzettl, T., Jouve, G., Francus, P., Ohlendorf, C., Gebhardt, C., and Zolitschka, B., and PASADO Science Team: Rock-magnetic proxies of wind intensity and dust since 51,200 cal BP from lacustrine sediments of Laguna Potrok Aike, southeastern Patagonia, EPSL, 411, 72-86, doi:10.1016/j.epsl.2014.11.007, 2015.

Loegering, M. J., Anka, Z., Autin, J., di Primio, R., Marchal, D., Rodriguez, J. F., Franke, D., and Vallejo, E.: Tectonic evolu- tion of the Colorado Basin, offshore Argentina, inferred from seismo-stratigraphy and depositional rates analysis, Tectonophysics, 604, 245-263, doi:10.1016/j.tecto.2013.02.008, 2013.

Lonardi, A. G. and Ewing, M.: Sediment transport and distribution in the Argentine Basin. 4. Bathymetry of the continental margin, Argentine Basin and other related provinces. Canyons and sources of sediments, Phys. Chem. Earth, 8, 79121, doi:10.1016/0079-1946(71)90016-4, 1971.

Martinod, J., Husson, L., Roperch, P., Guillaume, B., and Espurt, N.: Horizontal subduction zones, convergence velocity and the building of the Andes, Earth Planet Sc. Lett., 299, 299-309, doi:10.1016/j.epsl.2010.09.010, 2010.

Moulin, M., Aslanian, D., and Unternehr, P.: A new starting point for the South and Equatorial Atlantic Ocean, Earth-Sci. Rev., 98, 1-37, doi:10.1016/j.earscirev.2009.08.001, 2010.

Muñoz, A., Cristobo, J., Rios, P., Druet, M., Polonio, V., Uchipi, E., Acosta, J., and Atlantis Group: Sediment drifts and cold-water coral reefs in the Patagonian upper and middle continental slope, Mar. Petrol. Geol., 36, 70-82, doi:10.1016/j.marpetgeo.2012.05.008, 2012.

Pardo-Casas, F. and Molnar, P.: Relative motion of the Nazca (Farallon) and South-American plates since late Cretaceous time, Tectonics, 6, 233-248, doi:10.1029/TC006i003p00233, 1987.

Planke, S. and Berndt, C.: "Anordning for seismikkmåling", Patent 20021140, 2002.

Planke, S., Erikson, F. N., Berndt, C., Mienert, J., and Masson, D.: P-Cable High-Resolution Seismic, Oceanography, 22, 85-85, doi:10.5670/oceanog.2009.09, 2009.

Preu, B., Schwenk, T., Hernández-Molina, F. J., Violante, R., Paterlini, M., Krastel, S., Tomasini, J., and Spiess, V.: Sedimentary growth pattern on the northern Argentine slope: the impact of North Atlantic Deep Water on southern hemisphere slope architecture, Mar. Geol., 329-331, 113-125, doi:10.1016/j.margeo.2012.09.009, 2012.

Preu, B., Hernández-Molina, F. J., Violante, R., Piola, A. R., Paterlini, C. M., Schwenk, T., Voigt, I., Krastel, S., and Spiess, V.: Morphosedimentary and hydrographic features of the northern Argentine margin: the interplay between erosive, depositional and gravitational processes and its conceptual implications, Deep-Sea Res. Pt. I, 75, 157-174, doi:10.1016/j.dsr.2012.12.013, 2013.

Razik, S.: How magnetics and granulometry of continental margin sediments reflect terrestrial and marine environment of South America and West Africa. Dissertation for the doctoral degree in natural sciences (Dr. rer. nat.) at the Faculty of Geosciences of the Bremen University, 147 pp., 2014.

Razik, S., Chiessi, C. M., Romero, O. E., and von Dobeneck, T.: Interaction of the South American Monsoon System and the Southern Westerly Wind Belt during the last 14 kyr, Palaeogeogr. Palaeocl., 374, 28-40, doi:10.1016/j.palaeo.2012.12.022, 2013.

Riedinger, N., Formolo, M. J., Lyons, T. W., Henkel, S., Beck, A., and Kasten, S.: An inorganic geochemical argument for coupled anerobic oxidation of methane and iron reduction in marine sediments, Geobiology, 12, 172-181, doi:10.1111/gbi.12077, 2014.

Ross, R.: Some Eocene diatoms from South Atlantic cores, Part II., California Academy of Sciences, Occ. Papers, 123, 21-27, 1976.

Ryan, W. B. F., Carbotte, S. M., Coplan, J. O., O'Hara, S., Melkonian, A., Arko, R., Weissel, R. A., Ferrini, V., Goodwillie, A., Nitsche, F., Bonczkowski, J., and Zemsky, R.: Global Multi- 
Resolution Topography synthesis, Geochem. Geophy. Geosy., 10, Q03014, doi:10.1029/2008GC002332, 2009.

Shevenell, A. E.: Middle Miocene Southern Ocean cooling and Antarctic cryosphere expansion, Science, 305, 1766-1770, doi:10.1126/science.1100061, 2004.

Torsvik, T. H., Rousse, S., Labails, C., and Smethurst, M. A.: A new scheme for opening of the South Atlantic Ocean and the dissection of an Aptian salt basin, Geophys. J. Int., 177, 13151333, doi:10.1111/j.1365-246X.2009.04137.x, 2009.

Uenzelmann-Neben, G., Weber, T., Grützner, J., and Thomas, M.: Transition from the Cretaceous ocean to Cenozoic circulation in the western South Atlantic - A twofold reconstruction, Tectonophysics, doi:10.1016/j.tecto.2016.05.036, in press, 2016.
Violante, R. A., Paterlini, C. M., Costa, I. P., Hernández-Molina, F. J., Segovia, L. M., Cavallotto, J. L., Marcolini, S., Bozzano, G., Laprida, C., Garcia-Chapori, N., Bickert, T., and Spiess, V.: Sismostratigrafia y Evolucion Geomorfologica del Talud Continental Adyacente al Litoral del Este Bonarense, Argentina, Latin American Journal of Sedimentology and Basin Analysis, 17, 33 62, http://ref.scielo.org/qnx2ts, 2010.

Voigt, I., Henrich, R., Preu, B. M., Piola, A. R., Hanebuth, T. J. J., Schwenk, T., and Chiessi, C. M.: A submarine canyon as a climate archive - interaction of the Antarctic Intermediate Water with the Mar del Plata Canyon (Southwest Atlantic), Mar. Geol., 341, 46-57, doi:10.1016/j.margeo.2013.05.002, 2013. 